\title{
Incidentally diagnosed papillary carcinoma in a thyroglossal duct cyst. What is the next step? A case report and review of the literature
}

\author{
Professor Nashwan Mahgoob \\ Department of Surgery College of Medicine University of Mosul , Mosul , Iraq \\ Correspondence: nashwanmahgoob@yahoo.com
}

(Ann Coll Med Mosul 2020; 42 (2):190-194).

Received: $16^{\text {th }}$ July 2020; Accepted: $10^{\text {th }}$ Nove. 2020.

\section{ABSTRACT}

Thyroglossal duct cyst is the commonest congenital disorders of the thyroid gland. Rarely, it can be a malignant tumor which is picked up incidentally in postoperative histopathology. Although management is still a controversy, a careful treatment and follow up planning is necessary for the management of such condition. We present a case of a 16 -year-old female patient with thyroglossal duct cyst carcinoma .

Keywords: thyroglossal cyst, papillary thyroid carcinoma, congenital thyroid disease .

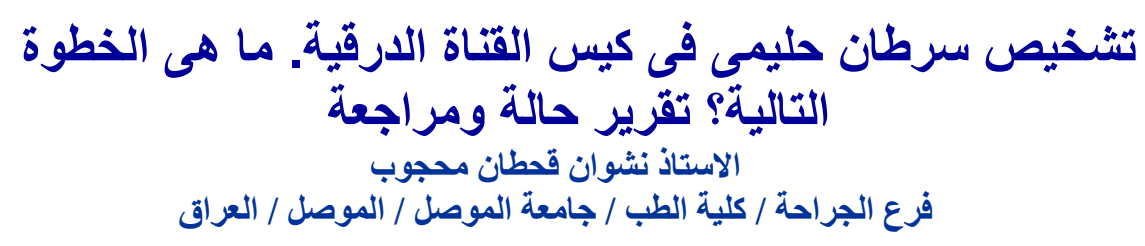

الخلاصة

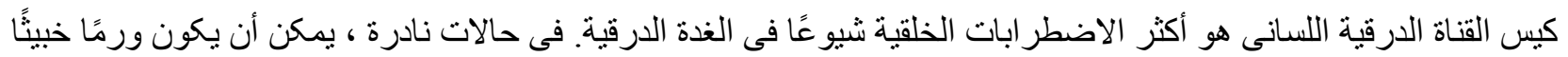

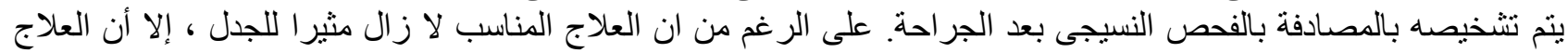

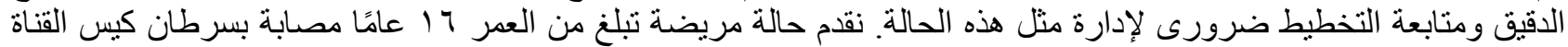

$$
\text { الكلمات المفتاحية: كيس قناة الغدة الدرقية ، ورم حلمى درقى ، امر اض الغدة الو لادي . }
$$

\section{INTRODUCTION}

T hyroid gland arises as a midline endodermal fold of the foregut, descends from foramen caecum in the tongue to the neck. The tract disappear in the 5th to10th week of intrauterine life, failure of involution gives rise to thyroglossal remnants ${ }^{1}$. Thyroglossal duct cysts present as an anterior painless midline neck mass, mostly at sub hyoid region. It is commonly seen at pediatric but it can be seen in other ages as well. it is usually benign but malignancy in the cyst can be seen in $1 \%$ of thyroglossal duct cysts ${ }^{2,3}$. The condition is more common in female ${ }^{4}$. Papillary carcinoma is the most common type $(80-95 \%)^{5}$. Brentano described the first carcinoma case in thyroglossal duct cyst in $1911^{6}$. The reported cases in world literature until 2017 are about 275 patients ${ }^{7}$. Sistrunk's operation is surgery of choice, but thyroidectomy or radioiodine therapy is still controversial and no consensus exists ${ }^{8}$. We present a case of a 16-year-old female who presented with a thyroglossal duct cyst in the subhyoid region, which was proved by postoperative histopathology as a papillary thyroid carcinoma. The report tried to evaluate the management issues involved and review of other literature and provides the use of Positron emission computerized tomography (PET CT) for follow up. 


\section{Case Report}

A 16 years female presented with a painless mass in her upper neck. The lesion was insidious, progressing gradually for two years. She did not complaint of dyspnea, dysphasia or any voice changes. No history of prior irradiation.

Neck examination showed a $2 \times 3 \mathrm{~cm}$ non-tender mass in the sub-hyoid region at midline, it was soft with smooth surface; the overlying skin was pinchable and normal. The mass was moving with tongue protrusion and deglutition (Figure 1). There were no palpable lymph nodes in the neck. The thyroid gland was not palpable with normal systemic examinations.

The investigations revealed normal thyroid state, ultrasound of thyroid gland showed cystic lesion of $2 \times 3 \mathrm{~cm}$ at sub hyoid area, normal thyroid gland and no lymphadenopathy in the neck. A diagnosis of sub hyoid thyroglossal duct cyst was made. The patient underwent Sistrunk's procedure. Intraoperative findings showed a $2 \times 3 \mathrm{~cm}$ cystic mass in the sub hyoid region, no adhesion to the surrounding structure. (Figure 2 and 3 ). The patient underwent uneventful recovery and discharged as a day case surgery.

Histopathological study showed typical papillary carcinoma with free resection margins, no angiolymphatic invasion seen.

Positron emission computerized tomography (PET CT) of the neck and whole body was done 6 weeks and one year after surgery, which showed no uptake in thyroid or in the neck neither in any other parts of the body. (Figure 3)

\section{DISCUSSION}

The most acceptable theory regarding thyroglossal duct cyst carcinoma origin is that it arises as de novo'. Other possible explanations include a multifocal origin in a genetically predisposed individual or a secondary from a papillary carcinoma at thyroid gland ${ }^{10}$.

The decision to perform total thyroidectomy in case of thyroglossal duct cyst carcinoma in normally looking thyroid ultrasound with the absence of lymph nodes in the neck was a management dilemma because it leads to life-long thyroid hormone supplement and a chances of hypoparathyroidism; on the other hand, it is needed to make the patient eligible for the radioiodine scans for further diagnosis and radio ablation if needed. It was believed that in the presence of the thyroid gland proper, each ectopic malignant thyroid tissue should be regarded as a metastasis ${ }^{11}$. However, Renard et al. ${ }^{12}$ showed that only 6 patients' who underwent total thyroidectomy, revealed carcinoma in the thyroid gland proper out of 43 patients with thyroglossal cyst carcinoma. Some authors prefer treating thyroglossal duct carcinoma by total thyroidectomy and I 131 ablation $^{13,14}$ while others insist that the malignancy is primary and Sistrunk operation is sufficient followed by long-term observation ${ }^{15-17}$.

The clinical presentation of thyroglossal duct cyst carcinoma is usually similar to benign thyroglossal duct cyst and it is often not easy to differentiate between the two by the imaging study. Difficulties arise in the diagnosis of these tumors as they present similarly to benign thyroglossal duct cysts. Most cases are diagnosed postoperatively ${ }^{18}$. Furthermore, the sensitivity of fine needle aspiration is about $50-60 \%$ in diagnosing carcinoma in such lesion ${ }^{19,20}$. Shirish $\mathrm{S}$, concluded that fine needle aspiration cytology findings in thyroid duct carcinoma are variable, alone may not be adequate for pre-treatment assessment in all cases ${ }^{21}$. Areej Shahin et. ${ }^{22}$ Found that $(61 \%)$ cases of surgically resected thyroid duct carcinoma were missed on prior FNA, it showed a diagnostic sensitivity of $62 \%$ and a positive predictive value (PPV) of $69 \%$ for the diagnosis of thyroid duct carcinoma and it is only moderately sensitive for a preoperative evaluation of thyroid duct carcinoma. Dong Hoon Lee et al ${ }^{23}$ showed that preoperative FNAC is not routinely necessary for diagnosing thyroid duct carcinoma in children especially given the concerns about possible injury, low sensitivity, and low positivepredictive value. Frozen section examination of the specimen should be considered when malignancy is a consideration. Danilovic et al. recommended use of frozen section to diagnose papillary carcinoma due to poor sensitivity of FNAB.

In their study, frozen section correctly diagnosed all cases of thyroglossal duct carcinomas based on suspicious findings on ultrasound $^{24}$. In our case there was no any suspicious of being malignant,that is why we did not performed frozen section study.

An acceptable guidelines revealed that total thyroidectomy is preferred in high-risk patients based on the following: male patient, more than 45 years in age, history of irradiation, $4 \mathrm{~cm}$ mass, extra-capsular invasion, positive nodal state, the presence of cold nodules in the thyroid gland on radioactive scan study ${ }^{25-27}$, in low-risk patients, Sistrunk's operation is enough but requires strict and regular follow up. Patel et al. ${ }^{28}$ found that the 5-year survival rate after Sistrunk's operation for thyroglossal duct cyst carcinoma in a low-risk patient is $100 \%$ and there is no need for total thyroidectomy. Furthermore, thyroid suppression therapy after the Sistrunk procedure in low-risk disease has probably no significant benefit ${ }^{5}$. 
This case fell into the low-risk category due to less than 45 years of age and less than $4 \mathrm{~cm}$ in size with no extra capsular invasion or lymph node involvement. Hence, Sistrunk's operation would be enough. The post-operative Pet CT can be of value in the evaluation of the condition and can be used for follow up.

\section{CONCLUSION}

Papillary carcinoma in a thyroglossal duct cyst is rare with controversies in its management. In low-risk patients, a Sistrunk's operation is enough and perfect, but in high-risk patients, more intervention should be done.

Using Pet CT postoperatively is of help in determining the next step.

\section{Acknowledgments}

Thanks for Soran private hospital team for their help and support.

Informed consent was taken from the patient and parents in the study.

\section{Disclosure Statement}

There is neither financial disclosure nor conflict of interest.
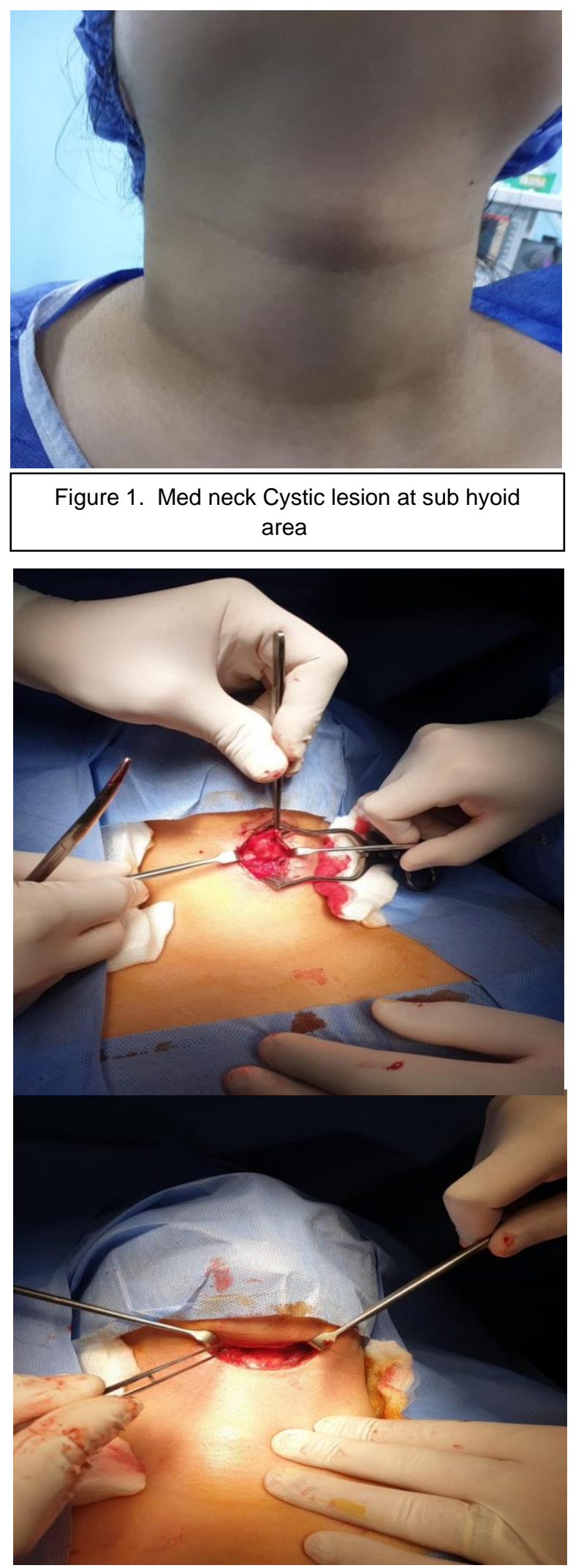

Figure 2,3 surgical procedure 


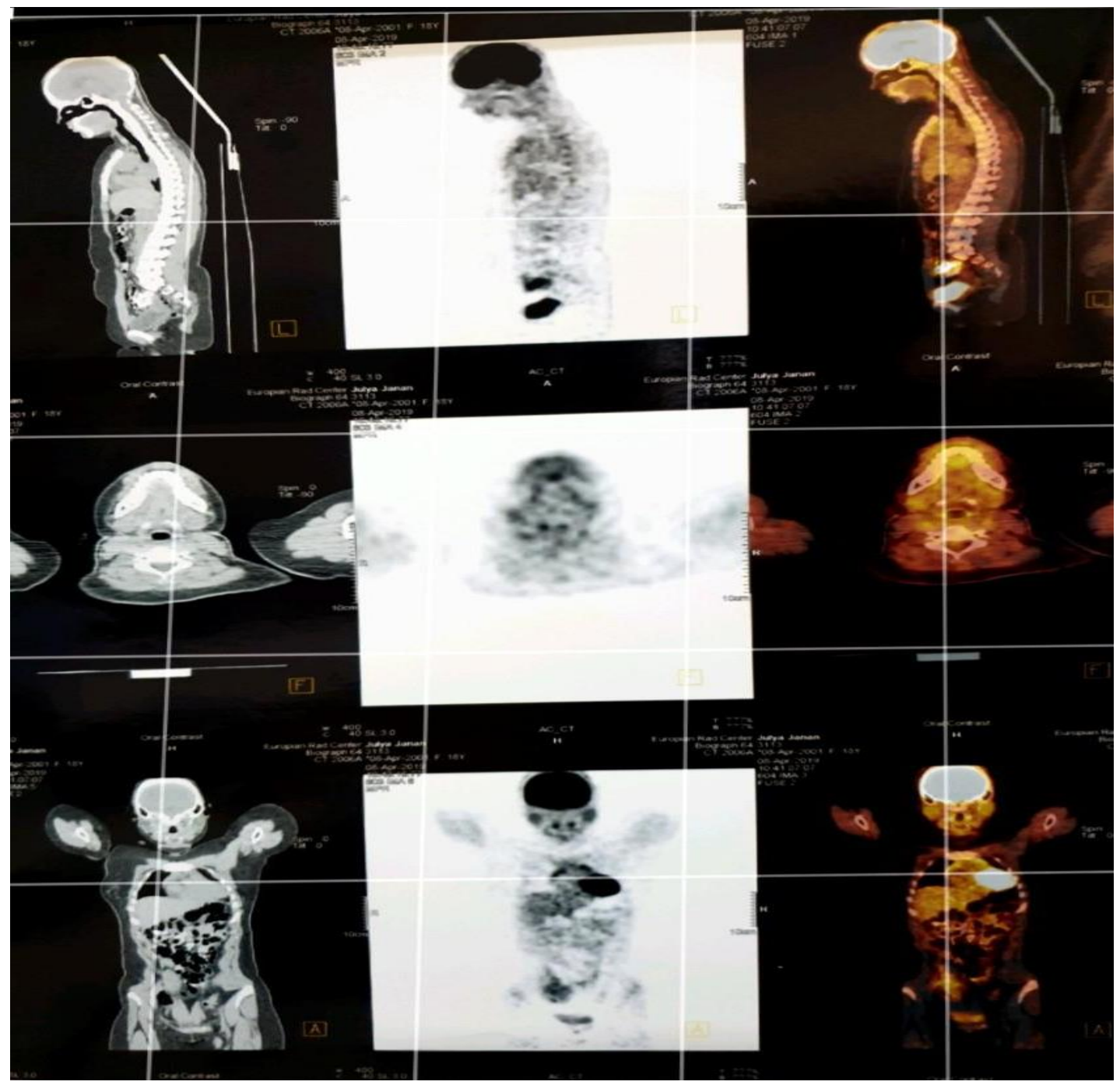

(PET CT) study

\section{REFERENCES}

1. Organ GM, Organ $\mathrm{CH}$., Jr Thyroid gland and surgery of the thyroglossal duct: exercise and applied embryology. World J Surg. 2000;24:88690. [PubMed] [Google Scholar].

2. Heshmati HM, Fatourechi V, van Heerden JA, et al. Thyroglossal duct carcinoma: report of 12 cases. Mayo Clin Proc. 1997;72:315-319. [Crossref], [PubMed], [Web of Science (B], [Google Scholar]

3.Cheon NJ, Lee YM, Lee JH, et al. Papillary carcinoma within a thyroglossal duct cyst in a 17year-old child. J Craniofac Surg. 2016;27:e282e283. [Crossref], [PubMed], [Web of Science ®], [Google Scholar].

4. Chu YC, Han JY, Han HS, Kim JM, Min SK, Kim YM. Primary papillary carcinoma arising in a thyroglossal duct cyst. Yonsei Med J. 2002;43:381-4. [PubMed] [Google Scholar]

5.Ishay A, Elmalah I, Luboshitzky R. Papillary carcinoma in a thyroglossal duct cyst. Isr Med Assoc J. 2008;10:312-3. [PubMed] [Google Scholar]

6. Brentano $\mathrm{H}$. Struma aberrata lingual mit druzen metastasen. Dtsch Med Wochenschr. 1911;37:665. [Google Scholar]

7.Sourabha Kumar Patro, Niveditha Damodharan, Ashwini Sood. Papillary carcinoma thyroid in a thyroglossal cyst: A management dilemma. Acta Oto-Laryngologica Case Reports. Volume 2, 2017 - Issue 1. https://doi.org/10.1080/23772484.2016.1270166

8. Balalaa N Megahed M, Ashari MA, Branicki F. Thyroglossal duct cyst papillary carcinoma. Case Rep Oncol. 2011 Jan; 29;4(1):39-43. doi: 
10.1159/000324405.

[PubMed], [Google Scholar].

[Crossref],

9. Hilger AW, Thompson SD, Smallman LA, Watkinson JC. Papillary carcinoma arising in a thyroglossal duct cyst: a case report and literature review. J Laryngol Otol. 1995;109:1124-1127. [Crossref], [PubMed], [Web of Science ${ }^{\circledR}$ ], [Google Scholar]

10. Tew S, Reeve TS, Poole AG, Delbridge L. Papillary thyroid carcinoma arising in thyroglossal duct cysts: incidence and management. Aust N Z J Surg. 1995;65 (10):717-718. [Crossref], [PubMed] , [Google Scholar]

11. Zink A, Raue F, Hoffmann R, Ziegler R. Papillary carcinoma in an ectopic thyroid. Horm Res. 1991;35:86-8. [PubMed] [Google Scholar]

12. Renard TH, Choucair RJ, Stevenson WD, Brooks WC, Poulos E. Carcinoma of the thyroglossal duct. Surg Gynecol Obstet. 1990;171:305-8. [PubMed] [Google Scholar]

13. Plaza CP, López ME, Carrasco CE, Meseguer LM, Perucho Ade L. Management of welldifferentiated thyroglossal remnant thyroid carcinoma: time to close the debate? Report of five new cases and proposal of a definitive algorithm for treatment. Ann Surg Oncol. 2006;13:745-52. [PubMed] [Google Scholar]

14. Heshmati HM, Fatourechi V, van Heerden JA, Hay ID, Goellner JR. Thyroglossal duct carcinoma: report of 12 cases. Mayo Clin Proc. 1997;72:315-9. [PubMed] [Google Scholar]

15. Chu YC, Han JY, Han HS, Kim JM, Min SK, Kim YM. Primary papillary carcinoma arising in a thyroglossal duct cyst. Yonsei Med J. 2002;43:381-4. [PubMed] [Google Scholar]

16. Weiss SD, Orlich CC. Primary papillary carcinoma of a thyroglossal duct cyst: report of a case and literature review. $\mathrm{Br} \mathrm{J}$ Surg. 1991;78:87-9. [PubMed] [Google Scholar]

17. Deshpande A, Bobhate SK. Squamous cell carcinoma in thyroglossal duct cyst. J Laryngol Otol. 1995;109:1001-4. [PubMed] [Google Scholar]

18. Anna Claudine F. Lahoz, Precious Eunice R. Grullo, Ryner Jose C. Carrillo. Thyroglossal Duct Carcinoma with Concurrent Papillary Thyroid Carcinoma: A Case Report Philipp J Otolaryngol Head Neck Surg 2020; 35 (1): 63-65

19. Falconieri G, Della Libera D, Zanella M. Papillary thyroid carcinoma of the thyroglossal duct cyst: comparative cytohistologic and immunochemical study of 2 new cases and review of the literature. Int $J$ Surg Pathol. 2001;9:65-71. [PubMed] [Google Scholar]

20. Yang YJ, Haghir S, Wanamaker JR, Powers $\mathrm{CN}$. Diagnosis of papillary carcinoma in a thyroglossal duct cyst by fine-needle aspiration biopsy. Arch Pathol Lab Med. 2000;124:139-42. [PubMed] [Google Scholar]

21. Chandanwale SS, Buch AC, Chawla KR, Mittal PU. Fine needle aspiration cytology of thyroglossal duct cyst: Diagnostic pitfalls and a study of 14 cases. Thyroid Res Pract 2013;10:104-7.

22. Areej Shahin 1, Frances $H$ Burroughs, John $P$ Kirby, Syed Z Ali. Thyroglossal duct cyst: a cytopathologic study of 26 cases. Diagnostic Cytopathology. 2005; 33: 6-365-451

23. Lee DH, Yoon TM, Lee JK, Lim SC. Is fine needle aspiration cytology appropriate for preoperatively diagnosing thyroglossal duct cysts in children under the age of 10 years? International Journal of Pediatric Otorhinolaryngology.2012 April ;76 (4) :480-482.

24. Danilovic DL, Marui S, Lima EU, Luiz AV, Brescia MD, Moyses RA, et al. Papillary carcinoma in thyroglossal duct cyst: role of fine needle aspiration and frozen section biopsy to guide surgical approach. Endocrine 2014 May; 46 (1):160-3. DOI: 10.1007/s12020-014-0173-6; PMID: 24493029

25. Forest VI, Murali R, Clark JR. Thyroglossal duct cyst carcinoma: case series. J Otolaryngol Head Neck Surg. 2011;40:151-156. [PubMed], [Web of Science ${ }^{\circledR}$ ], [Google Scholar].

26. Chrisoulidou A, Iliadou P, Doumala E, Mathiopoulu L, Boudina M, Alevizaki $M$ et al. Thyroglossal duct cyst carcinomas: is there a need for thyroidectomy? Hormones (Athens). 2013;12:522-528. [Crossref], [PubMed] , [Google Scholar]

27. Tharmabala M, Kanthan R. Incidental thyroid papillary carcinoma in a thyroglossal duct cyst management dilemmas. Int $\mathrm{J}$ Surg Case Rep. 2013;4:58-61. [Crossref], [PubMed] , [Google Scholar]

28. Patel SG, Escrig M, Shaha AR, Singl B; Shah JP. Management of well-differentiated thyroid carcinoma presenting within a thyroglossal duct cyst. J Surg Oncol. 2002;79:134-139.[Crossref], [PubMed], [Web of Science $\AA]$, , [Google Scholar] 